\title{
Book review of The Wandering Herd: The Medieval Cattle Economy of South East England c. 450-1450 by Andrew Margetts
}

\author{
Brian Kerr
}

\author{
Book details \\ Margetts, A. The Wandering Herd: The Medieval Cattle Economy of South East England c. 450-1450. Windgather Press, \\ 2021. 272 pages, ISBN 978-1-91118-879-7
}

Keywords: Pastoralism, Medieval history, Landscape history, Wood pasture

In 2003, the Knepp estate in Sussex made the bold step of releasing English longhorn cattle into a large enclosure, with the long-term aspiration of allowing these animals to essentially live wild. The cattle would remain outdoors throughout the year and the enclosure would be monitored but not managed: the herd was left to feed and calve without interference, and the land allowed to regenerate, firstly to scrub and then to woodland. This re-introduction was made thoughtfully after discussions with similar introductions of the Heck breed of cattle to polder land in the Netherlands.

Isabella Tree (2018) in her pioneering book which traces the radical transformation of the land at Knepp makes the case for this introduction of large herbivores into the landscape as being the logical next step in a process of re-wilding, or as she prefers the term 'wilding'. The striking cover picture of cattle grazing in woodland on the Knepp estate links the publication of The Wandering Herd by Andrew Margetts to these experimental re-introductions of herbivores to the English landscape. Re-wilding in Britain has moved beyond the first faltering steps of releasing a few beavers into a river and hoping for the best.

The sub-title of Margetts book, 'the medieval cattle economy in South-East England c 450-1450', is a

Correspondence:wbkerr47@gmail.com

Cranfield University School of Applied Sciences, Cranfield University, Bedford, UK reminder that this use of land for range pastoralism was once prevalent in England. The heart of this book is a very detailed description of the operation of this economy in the counties of Kent, Sussex and Surrey, centred on the Weald. It is easily forgotten, in the presence of neat regular enclosure fields, which we now regard as the norm, that the grazing of herbivores has for millennia shaped the habitats of England. The enthusiastic uptake by conservation agencies of gazing animals ranging from water buffalo in Suffolk, to wild boar in the Forest of Dean, is a timely reminder that large animals drive natural processes and the challenge of re-wilding is to understand how this works; the stocking densities required and how to manage both the herd (albeit in small numbers) and the public. The juxtaposition of an urban population who are re-discovering the draw of nature, but are unaccustomed to large animals outside a zoo enclosure, is likely to be fraught.

The author opens up a discussion on modern reintroductions in a brief three pages at the end of the book. He makes the important point that as the area of woodland increases across England, 'wood-pasture' as a land use should become increasingly the target for conservation agencies. An understanding of the full historical context for this class of land management, and the techniques applied, then becomes essential. Older practices such as the harvesting of 'tree hay' are forgotten pastoral techniques and may need to be re-discovered. A

(c) The Author(s). 2021 Open Access This article is licensed under a Creative Commons Attribution 4.0 International License, which permits use, sharing, adaptation, distribution and reproduction in any medium or format, as long as you give appropriate credit to the original author(s) and the source, provide a link to the Creative Commons licence, and indicate if changes were made. The images or other third party material in this article are included in the article's Creative Commons licence, unless indicated otherwise in a credit line to the material. If material is not included in the article's Creative Commons licence and your intended use is not permitted by statutory regulation or exceeds the permitted use, you will need to obtain permission directly from the copyright holder. To view a copy of this licence, visit http://creativecommons.org/licenses/by/4.0/. 
sense of perspective is advised as the cattle economy central to the livelihood of large sections of the medieval population cannot realistically be compared in scale to the small areas now being devoted to conservation grazing.

Today's tentative steps towards a more natural landscape will be interesting to the modern reader, but the thrust of this work is a very detailed and comprehensive account of the economy of cattle keeping in Sussex from the middle of the fifth to the fifteenth century. The flow of the eleven chapters moves from a description of the study area centred on the Sussex Weald through chapters detailing existing research; a detailed account of place name evidence; and descriptions of land use types such as common land, medieval parks, an account of animal bone assemblages; and the types of enclosure some of which have left an imprint on the modern landscape. The final sections include case studies and an attempt to pull together the threads in chapters entitled Discussion and Conclusion.

An appreciation of work hinges on an understanding of the distinctive nature of the landscapes of the study area, which spans some $9000 \mathrm{~km}^{2}$, south of the River Thames. The use of the author of the French concept of pays to sub-divide the landscape into natural regions, which can then be related to settlement types and ultimately to the livestock economy, is an elegant idea often overlooked in British topographic studies. By employing the term pays, accompanied by useful page figures, the reader is provided with a general feel for land, which brings together the geology, relief, present-day land use and historic and cultural affinities. The description and mapping of these pays in the early pages of the text provides an insight into the varied economy, later given a historic context in the following pages.

This is a handsomely produced book of over 270 pages complete with an exhaustive bibliography, a helpful list of abbreviations used in the text and a full listing of plates and figures. The use of LiDAR imagery in tracing enclosure structures is especially striking. While there are a few attractive colour plates of landscapes and grazing cattle, the monochrome photographs are in general underwhelming. The many black and white figures are clear and helpful. Less helpful is the absence of an index.

This book summarises a specific and focussed academic research project and may pose a daunting challenge for the general reader. The opening acknowledgement thanks an academic supervisor at the doctoral level and often the text has the feel of large sections being simply decanted from a thesis. The level of detail is commendable but exhausting, leaving the reader with the feeling that sympathetic but more book-focussed editing would have cleared away some of the understory and allowed the real economic arguments for this medieval use of land to see the light.

One aspect of the research which will hold the general interest is the detailed audit of place names, which are still found on modern maps and which tell a story of a past livestock economy. Words such as 'shieling' and 'fold' will be familiar but this reviewer was delighted to meet snoad (a clearing in the forest), or less technically a lufu stede (a place of love). Another delight is the painstaking mapping of a medieval road system, following the grain of the country and showing clearly the linkages with common land and known protected forest areas. These drove roads were the arteries of transhumance which made the pastoral economy work. The linkage here in lowland Britain is not based on movement across a climatic gradient to summer pasture but rather between favourable soils and the more marginal area, such as the high Weald. The economic effort in terms of the labour required to drive stock around 30 miles in some cases indicates the high status of the woodland pasture system. Following the Norman Conquest, more settled rural conditions in the twelfth century encouraged this pasture to evolve into standard farm enterprises with some arable land as the forest boundary was pushed back.

Margetts also questions our historical perceptions of what is often described as 'marginal land'. The application of this designation to the arc of Lower Greensand rocks across the study area is mirrored north of the Thames and even today these areas are described as 'marginal'. This ignores the historical fact that Cistercian and other monastic settlements operated many successful 'grange' farms and vineyards on these lands. The post-enclosure parkland landscape centred on large estates and grand houses is also clustered in this geographic zone. As Margetts explains, our understanding of land is often skewed by the value placed on cropped arable fields, which somehow register as more noteworthy than pasture and woodland.

There is little doubt that The Wandering Herd will find a respected place in the literature of medieval agriculture and economy and can be studied alongside the survey of land, recorded estate by estate across England in 1086 by the Domesday Book commissioners. Like all good research, this account opens up further avenues for investigation. How far can this complex pattern of a pastoral economy be extrapolated to other landscapes across Britain especially in the uplands? Does this historical work have any traction as Britain stumbles towards a changing pattern of land use with a mosaic of intensive commercial farming, conservation areas, greatly increased woodland cover and regenerative agriculture?

Throughout, this reviewer has been struck by the need for a popular-and shorter-account of historical 
pastoral landscapes and how these functioned. There may be a market for a book which can draw a line from detailed research, such as that of Margetts, to the growing use of large herbivores as a part of conservation efforts. Such an account would provide a platform for these new initiatives and make the medieval experience more widely understood. Andrew Margetts, perhaps in tandem with a writer with experience in conservation work, would seem the ideal person for this task.

\section{Acknowledgements}

Not applicable

\section{Author's contributions}

The book author has not read the review. The review author read and approved the final manuscript.

\section{Author's information}

None

\section{Funding}

The reviewer did not receive any funding.

Availability of data and materials

Not applicable

\section{Declarations}

Ethics approval and consent to participate

Not applicable

\section{Consent for publication}

Not applicable

\section{Competing interests}

The reviewer declares that he has no competing interests.

Received: 30 June 2021 Accepted: 1 July 2021

Published online: 27 September 2021

\section{Reference}

Tree, Isabella. 2018. Wilding: The return of nature to a British farm. London: Picador.

\section{Publisher's Note}

Springer Nature remains neutral with regard to jurisdictional claims in published maps and institutional affiliations.

\section{Submit your manuscript to a SpringerOpen ${ }^{\circ}$ journal and benefit from:}

- Convenient online submission

- Rigorous peer review

- Open access: articles freely available online

- High visibility within the field

- Retaining the copyright to your article 